\title{
Germination and growth of purple passion fruit seedlings under pre-germination treatments and mycorrhizal inoculation ${ }^{1}$
}

\author{
Joaquín Guillermo Ramírez Gil², Melissa Muñoz Agudelo², \\ Laura Osorno Bedoya ${ }^{3}$, Nelson Walter Osorio ${ }^{3}$, Juan Gonzalo Morales Osorio ${ }^{2}$
}

\section{ABSTRACT}

The cultivation of purple passion fruit plants has increased in Colombia, as a direct result of its well-accepted consumption. Therefore, there is a need for technological solutions aimed at the sustainable growth of its fruit, such as improving seed germination and decreasing phosphorus $(\mathrm{P})$ deficiencies, given its low availability in tropical soils. This study aimed to evaluate pre-germination treatments (control, apical and basal seed cuts, alternation of temperature, photoperiod, application of gibberellic acid and immersion in $96 \%$ of $\mathrm{H}_{2} \mathrm{SO}_{4}$ ) and mycorrhizal dependency of purple passion fruit plants, using three levels of $\mathrm{P}$ in the soil solution ( $0.002 \mathrm{mg} \mathrm{L}^{-1}, 0.02 \mathrm{mg} \mathrm{L}^{-1}$ and $\left.0.2 \mathrm{mg} \mathrm{L}^{-1}\right)$, in 35 combinations with or without the inoculation of the Glomus fasciculatum mycorrhizal fungus. A completely randomized design with five replications per treatment was used. The treatment with the most significant effect for reducing the dormancy of the purple passion fruit seeds is the immersion in $96 \%$ of $\mathrm{H}_{2} \mathrm{SO}_{4}$ for 20 minutes. This species shows a high mycorrhizal dependency, when coupled with $0.02 \mathrm{mg} \mathrm{L}^{-1}$ of $\mathrm{P}$ in the soil solution.

KEY-WORDS: Passiflora edulis f. edulis Sims; Glomus fasciculatum; seed dormancy; phosphorous fixing.

\section{INTRODUCTION}

Purple passion fruit (Passiflora edulis $\mathrm{f}$. edulis Sims) is a tropical crop grown between $600 \mathrm{~m}$ and 2,000 $\mathrm{m}$ of altitude. Commercial crops are cultivated mainly in Brazil, Colombia, Peru and Ecuador, where it is consumed as a fresh fruit or produced for exportation to Europe (Ruggiero et al. 1996, Nakasone \& Paull 1998, Riascos et al. 2011). In Colombia, this fruit is grown in Cundinamarca, Boyacá, Tolima and Huila, where the planted area

\section{RESUMO}

Germinação e crescimento de maracujazeiro roxo sob tratamentos pré-germinativos e inoculação micorrízica

O cultivo de maracujazeiro roxo tem aumentado na Colômbia, como resultado direto do seu consumo bem aceito. Diante disso, há necessidade de soluções tecnológicas voltadas para o crescimento sustentável do seu fruto, como a melhoria da germinação de sementes e diminuição das deficiências de fósforo (P), dada a sua baixa disponibilidade em solos tropicais. Assim, este estudo objetivou avaliar tratamentos pré-germinativos (controle, cortes da porção apical e basal das sementes, alternância de temperatura, fotoperíodo, aplicação de ácido giberélico e imersão em $96 \%$ de $\mathrm{H}_{2} \mathrm{SO}_{4}$ ) e a dependência micorrízica de plantas de maracujá roxo, utilizando-se três níveis de $\mathrm{P}$ na solução do solo ( $0,002 \mathrm{mg} \mathrm{L}^{-1}, 0,02 \mathrm{mg} \mathrm{L}^{-1}$ e $\left.0,2 \mathrm{mg} \mathrm{L}^{-1}\right)$, em 35 combinações com inoculação ou não do fungo micorrízico Glomus fasciculatum. Utilizou-se delineamento inteiramente casualizado, com cinco repetições por tratamento. $\mathrm{O}$ tratamento com efeito mais significativo sobre a redução da dormência das sementes de maracujá roxo é a imersão em $96 \%$ de $\mathrm{H}_{2} \mathrm{SO}_{4}$, durante 20 minutos. Esta espécie apresenta alta dependência micorrízica, quando conjugada com $0,02 \mathrm{mg} \mathrm{L}^{-1}$ de P na solução do solo.

PALAVRAS-CHAVE: Passiflora edulis f. edulis Sims; Glomus fasciculatum; dormência de sementes; fixação de fósforo.

and fruit production have grown steadily in recent years as a result of the increased demand (Gutiérrez et al. 2011, Riascos et al. 2011).

Crop sustainability requires technological improvements in agronomical practices, such as high quality seedling supply, prompt and accurate plant nutrition and integrated pest and disease management practices, such as bio-based incorporation.

Species belonging to the Passiflora genus are usually propagated through seeds (Miranda et al. 2009). However, seeds have a hard outer coating

1. Manuscript received in Dec./2014 and accepted for publication in Jul./2015 (http://dx.doi.org/10.1590/1983-40632015v4533273).

2. Universidad Nacional de Colombia, Facultad de Ciencias Agrarias, Departamento de Ciencias Agronómicas, Medellín, Antioquia, Colombia.E-mails: jgramireg@unal.edu.co,mmunoza@unal.edu.co,jgmoraleso@unal.edu.co.

3. Universidad Nacional de Colombia, Escuela de Biociencias, Facultad de Ciencias, Medellín, Antioquia, Colombia.

E-mails: lauraosornobedoya@gmail.com,nwosorio@gmail.com. 
covered by a resin that makes it impermeable, inducing exogenous dormancy, which is probably a combination of mechanical and chemical mechanisms, leading to low germination percentages (Pruthi 1963, Ellis et al. 1985).

In a study using seeds from three Passiflora species, Gutiérrez et al. (2011) applied seed pregermination treatments to overcome dormancy, promoting rapid and uniform germination. However, further research is needed, because variable germination rates are observed when available protocols are applied for seed germination.

The plant-arbuscular mycorrhizal fungi (AMF) symbiosis has proven to be beneficial for seedling growth, development, nutrient uptake, soil aggregation, product quality and plant defense responses against biotic and abiotic stresses in many cultivated plant species. These benefits result in a reduction of chemical inputs, environmental pollutants and production costs (Oliveira et al. 2013, Zou et al. 2013, Gobbato 2015, Pierart et al. 2015). It has been particularly important in soils with low phosphorus levels, such as tropical soils and those under drought stress conditions (Yano \& Takaki 2005, Osorio 2011, Ramirez et al. 2013). The inoculation of plants with AMF, during the seedling stage, can improve plant survival and development after transplantation to the fields, where they are more vulnerable (Roveda et al. 2007).

Despite the known benefits of plant mycorrhization, several conditions, such as soil type, fungus strain and host genotype, may limit association efficacy (Herrera-Peraza et al. 2011). Therefore, specific research should be performed for each plantmycorrhiza symbiosis for successful crop development.

Research on Passiflora edulis f. edulis mycorrhization has been scarce, with most reports being focused on the closely related Passiflora edulis f. flavicarpa. Passion fruit studies show relative mycorrhizal dependency (RMD) determined by the AMF species, abundance of antagonist microorganisms in the soil and soil P level (Cavalcante et al. 2001). Díaz et al. (2011) reported that purple passion fruit mycorrhizal colonization and number of spores were negatively affected by chemical fertilization. Previous researches suggest that AMF have good potential for the establishment of crop integrated management. Therefore, the investigation of AMF-purple passion fruit interactions may have important impacts on crop sustainability.
This study aimed to evaluate different treatments for improving purple passion fruit seeds germination and determine the mycorrhizal dependency of this species on the AMF Glomus fasciculatum.

\section{MATERIAL AND METHODS}

The experiment was performed between 2012 and 2013, in a greenhouse at the Universidad Nacional de Colombia, in Medellín $\left(6^{\circ} 15^{\prime} \mathrm{N}\right.$, $75^{\circ} 35^{\prime} \mathrm{W}$ and altitude of $1,495 \mathrm{~m}$ ), Colombia, at temperatures of $20-25^{\circ} \mathrm{C}$.

Purple passion fruits were collected from commercial crops located in Guatapé (Antioquia, Colombia), in a state of physiological maturity corresponding to stage five (Pinzón et al. 2007). Seeds were extracted from the pulp and submerged in tap water at room temperature $\left(\sim 22-25^{\circ} \mathrm{C}\right)$, for 48 hours, for easy manual mucilage removal (Rivera et al. 2002). Seeds were surface sterilized by calcium hypochlorite washing (3\% v/v in sterile distilled water) for one minute, followed by sterile distilled water rinsing for 30 seconds, then ethanol immersion ( $76 \% \mathrm{v} / \mathrm{v}$ in sterile distilled water, due to efficacy for seed surface sterilization) for one minute, rinsed with sterile distilled water for 30 seconds and covered by a mixture of carboxin + captan $\left(2 \mathrm{~g} \mathrm{~L}^{-1}\right.$ a.i. $)$ fungicide and Chlorpyrifos $\left(2 \mathrm{cc} \mathrm{L}^{-1}\right.$ a.i.) insecticide for 15 minutes. Later, the seeds were dried at room temperature in paper towels.

The pre-germination treatments evaluated were: T0: control; T1: $2 \mathrm{~mm}$ cut of the apical and basal seed ends, using a sterile surgical scalpel blade; T2: cold/warm stratification (12 hours at $4{ }^{\circ} \mathrm{C}$ and 12 hours at $\left.28{ }^{\circ} \mathrm{C}\right)$; T3: light (12 hours of darkness and 12 hours of light, using blue LED lights

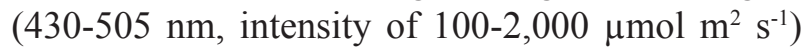
and red LED lights $(633-660 \mathrm{~nm}$, intensity of 200$3,500 \mu \mathrm{mol} \mathrm{m} \mathrm{m}^{2} \mathrm{~s}^{-1}$ ), at $22{ }^{\circ} \mathrm{C}$ average temperature; T4: gibberellic acid application (400 $\left.\mathrm{mg} \mathrm{L}^{-1}\right)$; T5: immersion in sulfuric acid (96\% v/v) for 1 minute; T6: immersion in sulfuric acid $(96 \% \mathrm{v} / \mathrm{v})$ for 5 minutes; T7: immersion in sulfuric acid $(96 \% \mathrm{v} / \mathrm{v})$ for 10 minutes; T8: immersion in sulfuric acid ( $96 \%$ $\mathrm{v} / \mathrm{v}$ ) for 20 minutes.

Seeds were incubated in humid chambers on absorbent paper at room temperature $\left(25^{\circ} \mathrm{C}\right)$ and $80-90 \%$ humidity with sterile distilled water. Each experimental unit consisted of 20 seeds and five 
repetitions were evaluated for each treatment. The percentage of germination (PG), average germination time (AGT) and average germination speed (AGS) were calculated following the procedures reported by Cardenas (2011). Seed viability was determined by the tetrazolium test (Gutiérrez et al. 2011), with seeds cut lengthwise on one end and submerged in a $0.5 \%(\mathrm{w} / \mathrm{v}) 2,3,5$-triphenyl-2H-tetrazolium chloride solution at $30^{\circ} \mathrm{C}$, for 24 hours, under dark conditions. Later the embryo was extracted and observed in a stereomicroscope, in order to visualize its color tone. Embryos showing intense red were considered viable, while the discoloured ones were considered dead.

For mycorrhizal dependency studies, soil from El Peñol (Antioquia, Colombia) was air-dried and passed through a $4 \mathrm{~mm}$ sieve. By soil analysis, the sample was identified as Andisol, with sand = $52 \%$, lime $=36 \%$ and clay $=44 \%$ (Bouyoucos); $\mathrm{pH}=4.8$ (water, $1: 2, \mathrm{v}: \mathrm{v})$; aluminum $=0.7 \mathrm{cmol}_{\mathrm{c}} \mathrm{kg}^{-1}$ $(\mathrm{KCl} 1 \mathrm{M}) ; \mathrm{Ca}=0.4 \mathrm{cmol}_{\mathrm{c}} \mathrm{kg}^{-1}, \mathrm{Mg}=0.2 \mathrm{cmol}_{\mathrm{c}} \mathrm{kg}^{-1}$ and $\mathrm{K}=0.1 \mathrm{cmol}_{\mathrm{c}} \mathrm{kg}^{-1}$ (ammonium acetate $1 \mathrm{M}$ ); $\mathrm{Fe}=37 \mathrm{mg} \mathrm{kg}^{-1}, \mathrm{Mn}=2 \mathrm{mg} \mathrm{kg}^{-1}, \mathrm{Cu}=1 \mathrm{mg} \mathrm{kg}^{-1}$ and $\mathrm{Zn}=1 \mathrm{mg} \mathrm{kg}^{-1}$ (Olsen-EDTA); $\mathrm{B}=0.1 \mathrm{mg} \mathrm{kg}^{-1}$ (hot water); $\mathrm{S}=2 \mathrm{mg} \mathrm{kg}^{-1}$ (calcium phosphate $0.008 \mathrm{M}$ ); $\mathrm{NO}_{3}^{-}=2 \mathrm{mg} \mathrm{kg}^{-1}$ (aluminum sulfate $0.025 \mathrm{M}$ ); $\mathrm{NH}_{4}^{+}=$ $6 \mathrm{mg} \mathrm{kg}{ }^{-1}(\mathrm{KCl} 1 \mathrm{M}) ; \mathrm{P}=1 \mathrm{mg} \mathrm{kg}^{-1}$ (Bray II); soluble $\mathrm{P}=0.001 \mathrm{mg} \mathrm{L}^{-1}\left(0.01 \mathrm{M}\right.$ of $\left.\mathrm{CaCl}_{2}\right)$; and organic material content $=6 \%$.

The soil moisture holding capacity and calcium incubation curve and phosphorus sorption isotherm tests (Fox \& Kamprath 1970) were performed for the development of mycorrhizal dependency experiments under appropriate conditions (Habte \& Manjunath 1991): $\mathrm{pH}$ of 5.6 (by adding $1.3 \mathrm{~g}$ of $\mathrm{CaO}$ per $\mathrm{kg}$ of soil, according to the incubation curve result) and $\mathrm{P}$ solution at $0.002 \mathrm{mg} \mathrm{L}^{-1}, 0.02 \mathrm{mg} \mathrm{L}^{-1}$ and $0.2 \mathrm{mg} \mathrm{L}^{-1}$, applied as $\mathrm{KH}_{2} \mathrm{PO}_{4}$ (Habte \& Manjunath 1991). The soil was autoclaved at $121{ }^{\circ} \mathrm{C}$ and $0.1 \mathrm{MPa}$, for two cycles of one hour each. A total of $500 \mathrm{~g}$ of sterile soil (dry base) were added to each pot and watered as needed to keep $50 \%$ of the soil moisture holding capacity with Hoagland $\mathrm{P}$-free nutritive solution $\left[\mathrm{N}=50 \mathrm{mg} \mathrm{L}^{-1}\left(\mathrm{KNO}_{3}\right) ; \mathrm{K}=132 \mathrm{mg} \mathrm{L}^{-1}\left(\mathrm{KNO}_{3}\right) ; \mathrm{Ca}=\right.$ $120 \mathrm{mg} \mathrm{L}^{-1}\left(\mathrm{Ca}\left(\mathrm{NO}_{3}\right)_{2}\right) ; \mathrm{Mg}=106 \mathrm{mg} \mathrm{L}^{-1}\left(\mathrm{MgSO}_{4}\right)$; $\mathrm{S}=204 \mathrm{mg} \mathrm{L}^{-1}\left(\mathrm{MgSO}_{4}\right) ; \mathrm{Zn}=10 \mathrm{mg} \mathrm{L}^{-1}\left(\mathrm{ZnSO}_{4}\right)$; $\mathrm{Cu}=5 \mathrm{mg} \mathrm{L}^{-1}\left(\mathrm{CuSO}_{4}\right) ; \mathrm{B}=0.8 \mathrm{mg} \mathrm{L}^{-1}\left(\mathrm{H}_{3} \mathrm{BO}_{3}\right) ; \mathrm{Mn}=$ $1.81 \mathrm{mg} \mathrm{L}^{-1}\left(\mathrm{MnCl}_{2}\right)$; and $\left.\mathrm{Mo}=0.5 \mathrm{mg} \mathrm{L}^{-1}\left(\mathrm{H}_{2} \mathrm{MoO}_{4}\right)\right]$.

Seedlings grew from seeds as described using the pre-germination treatment T8 (Table 1). In each pot $(15 \mathrm{~cm}$ in height, $20 \mathrm{~cm}$ in diameter and $1 \mathrm{~kg}$ of soil capacity at $50 \%$ moisture basis with sterile distilled water), three seedlings were planted. After two weeks, only the best seedling was left in the pot. The G. fasciculatum $(\mathrm{GF} 1 \mathrm{H})$ strain used was originally provided by Dr. M. Habte, from the University of Hawaii (Honolulu, USA), and subsequently multiplied in sorghum roots and kudzu in the Ecology and Environmental Conservation Laboratory at the Universidad Nacional de Colombia, in Medellín. Crude inoculum preparation containing G. fasciculatum was applied to the soil, at a rate of $35 \mathrm{~g}$ of inocula $\mathrm{kg}^{-1}$ of soil, for a final average concentration of 47 infective mycorrhizal propagules $\mathrm{g}^{-1}$ of soil, determined according to the most probable number method (Porter 1979). Autoclaved $\left(120^{\circ} \mathrm{C}\right.$, $0.1 \mathrm{MPa}$, for 60 minutes) crude inocula $\left(35 \mathrm{~g} \mathrm{~kg}^{-1}\right)$ plus $10 \mathrm{ml}$ of a suspension (10\%) obtained from inocula filtered through a $10 \mu \mathrm{m}$ filter paper were applied to the soil as a control.

A completely randomized experimental design with factorial arrangement was implemented, consisting of the combination of three levels of $\mathrm{P}$

Table 1. Effect of pre-germination treatments on purple passion fruit seeds (Medellín, Colombia, 2012/2013).

\begin{tabular}{ccccc}
\hline Treatment & Germination (\%) & AGT (days) & AGS (days) & Viability (\%) \\
\hline T0 & $72.0 \mathrm{a}$ & $28.3 \mathrm{a}$ & $1.2 \mathrm{a}$ & $85.3 \mathrm{a}$ \\
T1 & $50.0 \mathrm{~b}$ & $14.2 \mathrm{~b}$ & $1.3 \mathrm{a}$ & $55.8 \mathrm{c}$ \\
T2 & $71.0 \mathrm{a}$ & $25.2 \mathrm{a}$ & $1.3 \mathrm{a}$ & $81.2 \mathrm{a}$ \\
T3 & $69.2 \mathrm{a}$ & $27.9 \mathrm{a}$ & $1.5 \mathrm{a}$ & $86.9 \mathrm{a}$ \\
T4 & $68.2 \mathrm{a}$ & $24.5 \mathrm{a}$ & $1.5 \mathrm{a}$ & $78.9 \mathrm{ab}$ \\
T5 & $66.2 \mathrm{a}$ & $21.3 \mathrm{ab}$ & $1.4 \mathrm{a}$ & $84.3 \mathrm{a}$ \\
T6 & $67.9 \mathrm{a}$ & $15.2 \mathrm{~b}$ & $1.6 \mathrm{a}$ & $86.1 \mathrm{a}$ \\
T7 & $68.3 \mathrm{a}$ & $16.3 \mathrm{~b}$ & $1.8 \mathrm{~b}$ & $75.3 \mathrm{~b}$ \\
T8 & $67.9 \mathrm{a}$ & $10.3 \mathrm{c}$ & $2.8 \mathrm{c}$ & $79.1 \mathrm{ab}$ \\
\hline
\end{tabular}

AGT: average germination time; AGS: average germination speed. Averages followed by different letters indicate that they are significantly different, according to the Tukey test $(\mathrm{p} \leq 0.01)$. 
in the soil solution $\left(0.002 \mathrm{mg} \mathrm{L}^{-1}, 0.02 \mathrm{mg} \mathrm{L}^{-1}\right.$ and $\left.0.2 \mathrm{mg} \mathrm{L}^{-1}\right)$ and two levels of mycorrhizal inoculation: inoculated $(\mathrm{M}+)$ and uninoculated $(\mathrm{M}-)$. The experimental unit consisted of one plant and each treatment had five replicates. The experiment was repeated twice.

Ninety days after the treatment started, height $(\mathrm{cm})$, stem base diameter $(\mathrm{mm})$, dry biomass $(\mathrm{g})$ $\left(60{ }^{\circ} \mathrm{C}\right.$, for 72 hours), leaf area $\left(\mathrm{cm}^{2}\right)$ and leaf phosphate content $(\%)$ were quantified. Leaf phosphate content was determined by non-destructive samples, using the blue molybdate method (Murphy \& Riley 1962, Aziz \& Habte 1987). Mycorrhizal colonization was determined by fuchsine acid staining $(0.15 \%)$, for 48 hours (Kormanik et al. 1980). Roots were discolored with $\mathrm{KOH}(10 \%)$, for 24 hours (Phillips \& Hayman 1970). The intensity of the mycorrhizal colonization was quantified using the interception lines method (Giovanettie \& Mosse 1980). Mycorrhizal dependency (MD) was calculated with the total dry material value, using the formula proposed by Plenchette et al. (1983). MD classification was performed as reported by Habte \& Manjunath (1991).

For each variable evaluated, data homoscedasticity and normality were determined, using the criteria proposed by Levene and KolmogorovSmirnov, respectively. Data were analyzed by Anova and means compared with the Tukey test $(\mathrm{p} \leq 0.01)$, using the R Commander software.

\section{RESULTS AND DISCUSSION}

Significant reduction $(\mathrm{p}<0.01)$ on germination percentage (50\%) and seed viability $(55.8 \%)$ were found when the cut of the apical and basal seed (T1) was applied. These values were the lowest $(\mathrm{p}<0.01)$ of all treatments, including the control (T0) (Table 1). The average germination time (AGT) values were grouped into three different categories, by the Tukey test: cold/warm stratification (T2), light alternation (T3), gibberellic acid application (T4) and immersion in sulfuric acid for 1 minute (T5), with no decrease in the AGT ( $p>0.01)$, when compared to T0; T1 immersion in sulfuric acid for 5 minutes (T6) and immersion in sulfuric acid for 10 minutes (T7), with a significant decrease in the AGT, concerning T0; immersion in sulfuric acid for 20 minutes (T8), with the highest decrease for the AGT (Table 1). Results obtained for average germination speed (AGS) showed that T8 had the highest value of seeds germinated per day, followed by $\mathrm{T} 7$, which performed significantly better than T1, T2, T3, T4, T5, T6 and the control (T0) (Table 1) (Figure 1).

Results indicate that treating seeds with sulfuric acid at $96 \%$ for 20 minutes (T8) improves the germination process for purple passion fruit without compromising its viability (T8) (Table 1). With $\mathrm{T} 8$, it was possible to reduce the germination time in 18 days, on average, when compared to the control (T0). T1, T5 and T6 showed inferior AGT values, when compared to the corresponding control. However, this tendency did not coincide with the AGS values observed, because seeds germinated at disuniform germination rates, causing high variance and resulting in no significant differences, according to the Tukey test $(\mathrm{p}>0.05)$.

Gutiérrez et al. (2011) reported that apical and basal cuts in purple passion fruit seeds improved AGT, without affecting AGS, viability or seed germination percentage. In the present study,

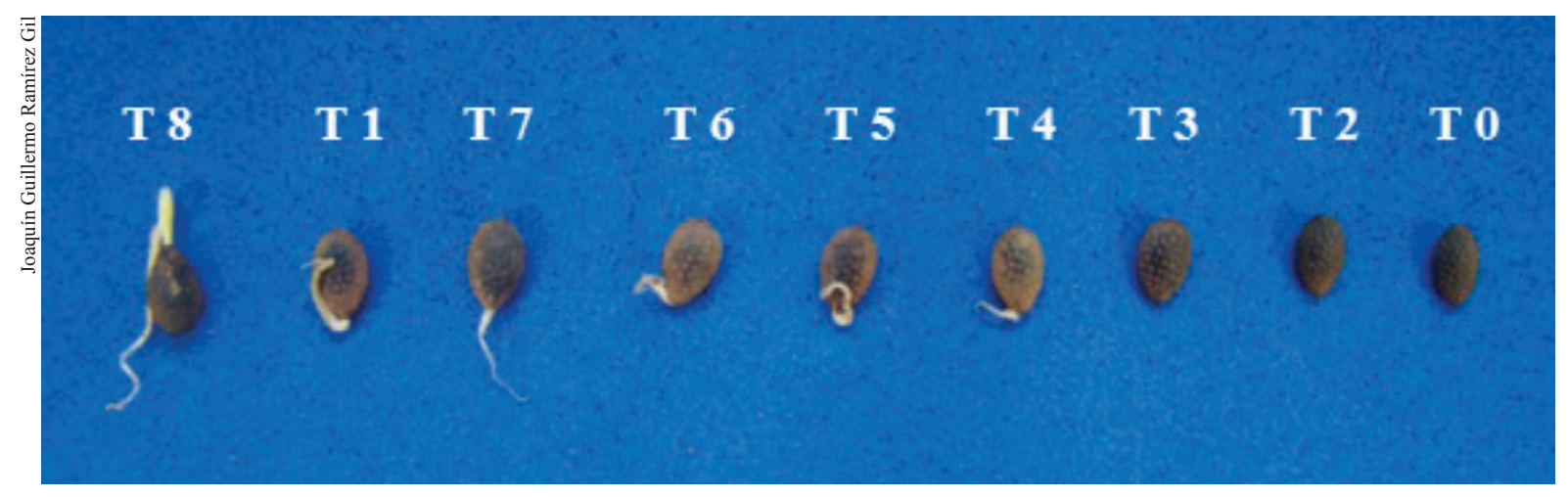

Figure 1. Visual appearance of the pre-germination treatments in the purple passion fruit seeds at 25 days after treatment application (Medellín, Colombia, 2012/2013). 
cutting off the seed ends (T1) reduced AGT, but also decreased the germination percentage and viability. The same authors (Gutiérrez et al. 2011) did not observe a positive effect on AGT, when soaking seeds in $49 \%$ and $98 \%$ of $\mathrm{H}_{2} \mathrm{SO}_{4}$ for 1,3 and 5 minutes, in agreement with our results. In the present study, a significant positive effect was only found after soaking seeds in sulfuric acid at $96 \%$ for 5,10 and 20 minutes, without apparent embryo damage, since viability was not affected by T8 $(\mathrm{p}>0.01)$, if compared to the control (T0).

Seeds treated with gibberellic acid (400 $\mathrm{mg} \mathrm{L}^{-1} \mathrm{ppm}$ ), temperature change (hot-cold), light and dark alternation, and $96 \%$ of sulfuric acid for 1 to 5 minutes did not break dormancy, as previously reported for species belonging to the Passiflora genus, suggesting inter and even intraspecific variation effect dormancy mechanisms, and therefore response to treatments to break it (Delanoy et al. 2006, Balaguera et al. 2010, Mabundza et al. 2010, Gomes et al. 2011, Cárdenas 2011). Results obtained

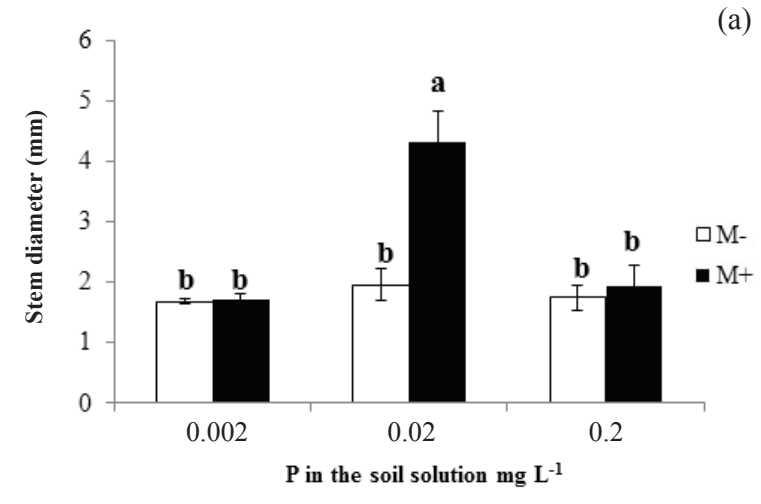

(a)
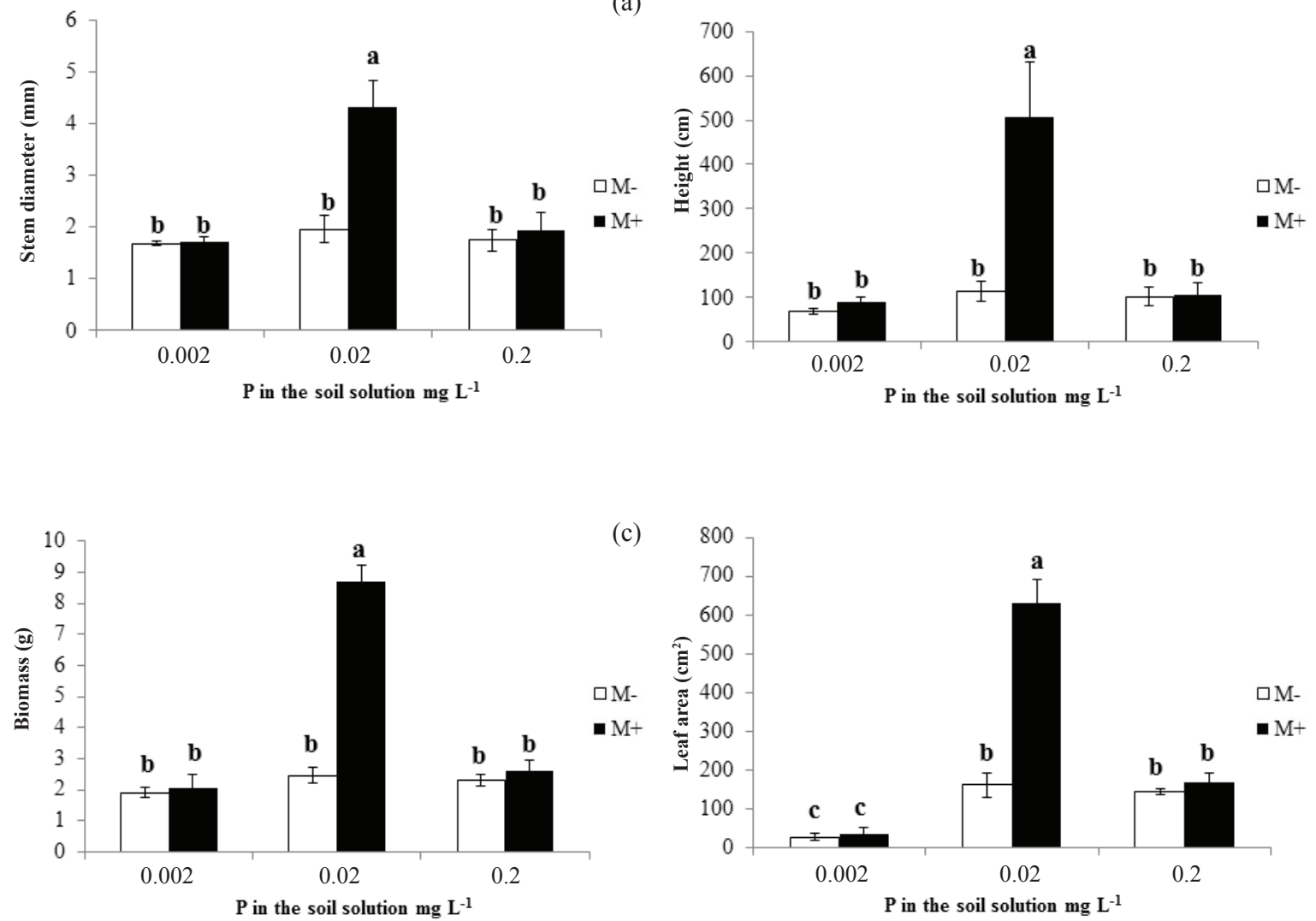

(d)

Figure 2. Effect of inoculation with G. fasciculatum, under three levels of $\mathrm{P}$ in the soil solution, on the biometric variables of purple passion fruit seedlings (Medellín, Colombia, 2012/2013). Error bars represent the standard deviation. Different letters indicate significant differences, according to the Tukey test $(\mathrm{p} \leq 0.01)$.

e-ISSN 1983-4063 - www.agro.ufg.br/pat - Pesq. Agropec. Trop., Goiânia, v. 45, n. 3, p. 257-265, Jul./Sep. 2015 
All plants inoculated with G. fasciculatum $(\mathrm{M}+)$ presented mycorrhizal colonization, while those in the uninoculated substrate (M-) did not develop AMF structures (Figure 3a). The colonization was significantly greater $(\mathrm{p}<0.01)$ with $\mathrm{P}$ levels of $0.02 \mathrm{mg} \mathrm{L}^{-1}$ in the soil, when compared to the other treatments, showing an average value of $51.4 \%$ (Figure 3a). For P values of $0.002 \mathrm{mg} \mathrm{L}^{-1}$ an intermediate value of mycorrhizal colonization was found (20.4\%), and for $0.2 \mathrm{mg} \mathrm{P} \mathrm{L}^{-1}$ the lowest value was observed $(7.6 \%)(\mathrm{p}<0.01)$. These results
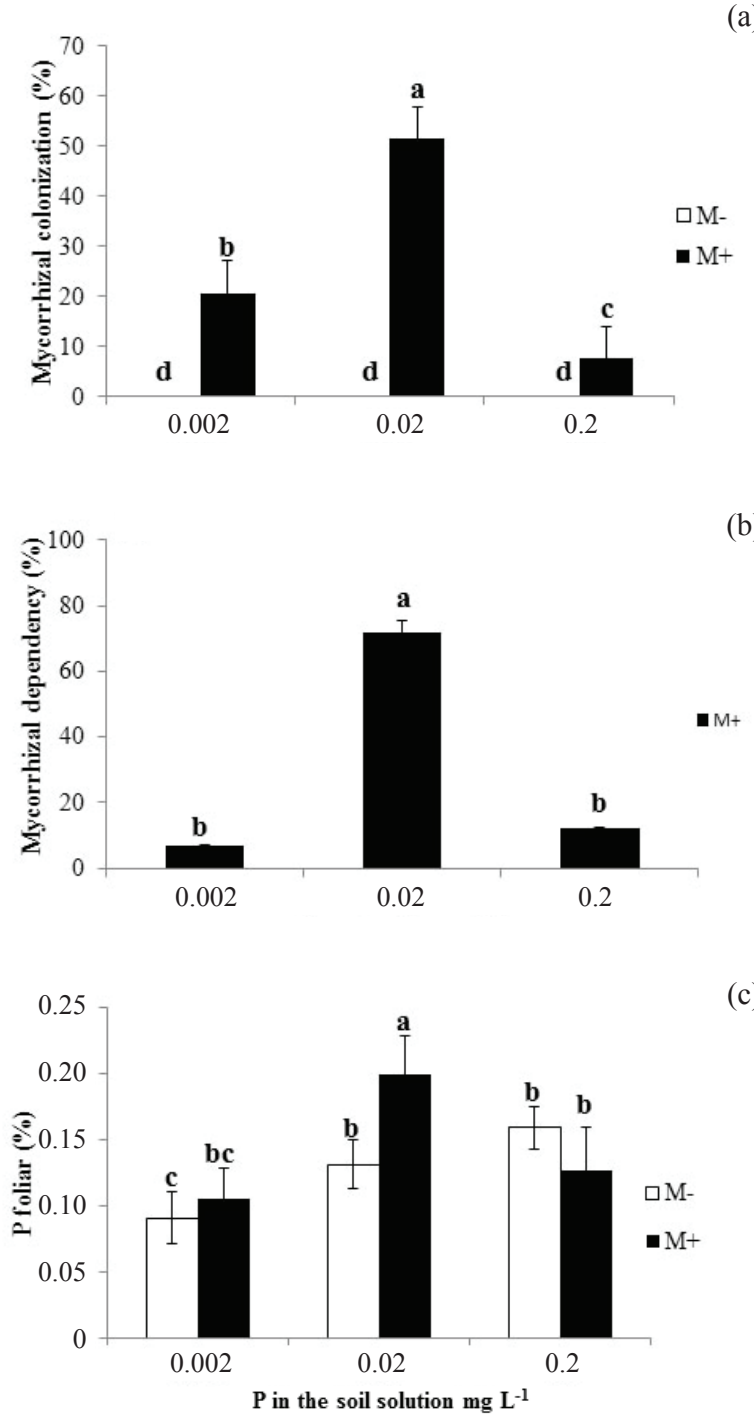

Figure 3. Effect of seedling inoculation with G. fasciculatum, together with three levels of $\mathrm{P}$ in the soil solution, on the variables mycorrhizal colonization, mycorrhizal dependency and foliar P content (Medellín, Colombia, 2012/2013). Error bars represent standard deviation. Different letters indicate significantly different averages, according to the Tukey test $(\mathrm{p} \leq 0.01)$. suggest that mycorrhizal colonization for purple passion fruit depends on the $\mathrm{P}$ level present in the soil solution.

Díaz et al. (2011) reported similar results, working with the same passion fruit species: under field conditions for the same species, mycorrhizal colonization values oscillated between $35.6 \%$ and $59.8 \%$, depending on the soil nutrient levels.

Significantly higher $(\mathrm{p}<0.01)$ mycorrhizal dependency $(71.7 \%$ ) (Figure $3 b)$ was observed when the soil contained $0.02 \mathrm{mg}$ of $\mathrm{P} \mathrm{L}^{-1}$ than with the other two levels of soluble P studied (12.0\% for $0.2 \mathrm{mg} \mathrm{L}^{-1}$ and $6.7 \%$ for $\left.0.002 \mathrm{mg} \mathrm{L}^{-1}\right)$. Based on the categorization proposed by Habte \& Manjunath (1991), these findings indicate that purple passion fruit plants show a higher mycorrhizal dependency $(>50 \%)$ at $0.02 \mathrm{mg} \mathrm{P} \mathrm{L}^{-1}$. Foliar P concentration (Figure 3c) was significantly higher $(\mathrm{p}<0.01)$ when $G$. fasciculatum was inoculated with a soluble P level of $0.02 \mathrm{mg} \mathrm{L}^{-1}$. Significant differences were not found between the other treatments $(p>0.05)$.

In the present research, the inoculation with the G. fasciculatum strain, when the P level in the soil solution was $0.02 \mathrm{mg} \mathrm{L}^{-1}$, clearly favored the growth of the purple passion fruit plant (Figure 4). Similar effects have been previously reported for other plant species at the same or close levels of $\mathrm{P}$ in the soil solution (Muthukumar et al. 2003, González \& Osorio 2008, Sierra et al. 2009, Osorio 2011, Ramirez et al. 2013).

Mycorrhizal colonization, mycorrhizal dependency and foliar $\mathrm{P}$ indicate that high $\left(>0.2 \mathrm{mg} \mathrm{L}^{-1}\right)$ or very low $\left(<0.002 \mathrm{mg} \mathrm{L}^{-1}\right) \mathrm{P}$ concentrations in the soil solution negatively affect the symbiotic relationship between the plant and the AMF, as reported here (Figure 3c) and for other plant species (González \& Osorio 2008, Ramirez et al. 2013). Previous researches suggest that high levels of $\mathrm{P}$ may induce the deactivation of $\mathrm{P}$ transporters in the mycorrhizal hyphae, what prevents the $\mathrm{P}$ absorption into the plant (Zandavalli et al. 2004, Osorio 2011). Our results indicate that high levels of $\mathrm{P}$ may also inhibit AMF colonization. AMF application is a suitable alternative for the establishment of an integrated agricultural system management, being an outstanding solution to improve the phosphorus use efficiency. Other comparative advantages of plant mycorrhization have been observed, such as improved plant 


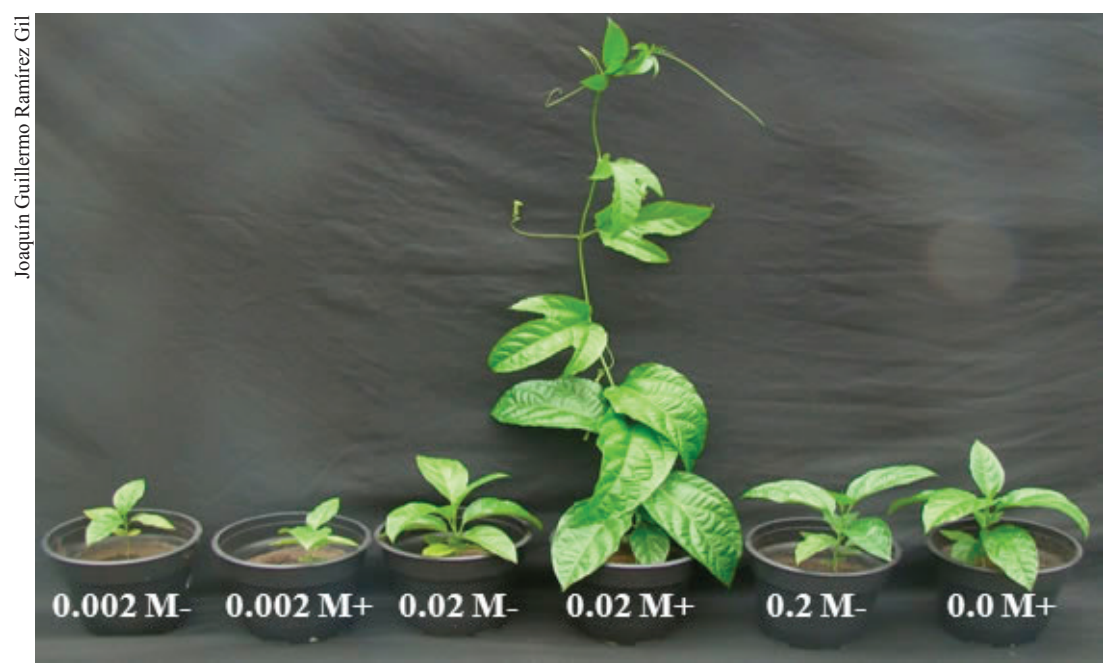

Figure 4. Purple passion fruit seedlings at 90 days after inoculation with G. fasciculatum and three P levels in the soil solution (Medellín, Colombia, 2012/2013).

tolerance to biotic and abiotic stresses, by increased root development and amplification of the soil volume exploration (Rodríguez et al. 2003, Yano \& Takaki 2005).

The purple passion fruit planted area has increased in Colombia, also increasing the demand for high quality seedlings. According to Gutiérrez et al. (2011), current nursery practices do not fulfill the high standards required by the fruit farmers and the market. Purple passion fruit crops are grown mainly in the tropical Andean mountains, where $\mathrm{P}$ absorbing soils are frequent, therefore limiting plant growth. Mycorrhiza-plant association may improve passion fruit yield, since this fungi may make the fixed $\mathrm{P}$ available into the soil solution for plant uptake (Ozane \& Shaw 1967, Osorio 2011).

As the beneficial effects identified for mycorrhiza application are conditioned on soil properties and agronomical practices, it is important that researches continue to support the most efficient AMF use on soil. Based on previous and on our own results, it is recommended to apply AMF during the early stages of development, when the $\mathrm{P}$ demand is high and plants are more vulnerable to environmental stresses. Thus, based on the present study, it is recommend the use of concentrated sulfuric acid (96\%) to significantly improve seed germination and germination time reduction, as well as the use of AMF to improve seedling growth and development.

\section{CONCLUSIONS}

1. The treatment with $96 \%$ of sulfuric acid, for 20 minutes, improves the average germination speed and decreases the average germination time of purple passion fruit seeds, without negatively affecting seeds germination and viability.

2. Purple passion fruit plants present high mycorrhizal dependency on the arbuscular mycorrhizal fungi G. fasciculatum, when the concentration of soluble $\mathrm{P}$ in the soil solution reaches around $0.02 \mathrm{mg} \mathrm{L}^{-1}$.

\section{ACKNOWLEDGMENTS}

Authors are grateful to the Universidad Nacional de Colombia in Medellín (Departamento de Ciencias Agronómicas of the Facultad de Ciencias Agrarias and Facultad de Ciencias of the Escuela de Biociencias), for financing this study.

\section{REFERENCES}

AZIZ, T.; HABTE, M. Determining vesicular arbuscular mycorrhizal effectiveness by monitoring P status of leaf disk. Canadiam Journal of Microbiology, Ottawa, v. 33, n. 1, p. 1097-1101, 1987.

BALAGUERA, H.; ÁLVAREZ, J.; CÁRDENAS, J. Efecto de la estratificación fría y la cobertura plástica en semillas de gulupa (Passiflora edulis Sims.) para la obtención de plántulas. Revista UDCA Actualidades y Divulgación Científica, Bogotá, v. 13, n. 2, p. 89-97, 2010. 
CÁRDENAS, J. Morfología y tratamientos pregerminativos de semillas de granadilla (Passiflora ligularis Juss.). 2011. 92 f. Tesis (Maestria en Ciencias Agrarias) - Universidad Nacional de Colombia, Bogotá, 2011.

CAVALCANTE, U. et al. Mycorrhizal dependency of passion fruit (Passiflora edulis f. flavicarpa). Fruits, Montpellier, v. 56, n. 1, p. 317-324, 2001.

DELANOY, M. et al. Germination of Passiflora mollissima (Kunth) L. H. Bailey, Passiflora tricuspis Mast. and Passiflora nov sp. seeds. Scientia Horticulturae, Amsterdam, v. 110, n. 1, p. 198-203, 2006.

DÍAZ, D. et al. Efecto de la aplicación de diferentes fertilizantes sobre la actividad micorrizal en gulupa. Suelos Ecuatoriales, Bogotá, v. 41, n. 2, p. 115-121, 2011.

ELLIS, R.; HONG, T.; ROBERTS, E. Handbook of seed technology for gene banks. Rome: IBPGR, 1985.

FOX, R.; KAMPRATH, E. Phosphate sorption isotherms for evaluating the phosphate requirements of soils. Soil Science Society of America Proceedings, Wisconsin, v. 34, n. 1, p. 902-907, 1970.

GIOVANNETTI, M.; MOSSE, M. An evaluation of techniques for measuring vesicular-arbuscular mycorrhizal infection in roots. New Phytologist, London, v. 84, n. 1, p. $489-500,1980$.

GOBBATO, E. Recent developments in arbuscular mycorrhizal signaling. Current Opinion in Plant Biology, Amsterdam, v. 26, n. 1, p. 1-7, 2015.

GOMES, J. et al. Germinação de sementes de Passiflora setacea e dormência induzida pelo armazenamento. Revista Brasileira de Sementes, Viçosa, v. 33, n. 1, p. 80$85,2011$.

GONZÁlEZ, O.; OSORIO, W. Determinación de la dependencia micorrizal del lulo. Acta Biológica Colombiana, Bogotá, v. 13, n. 2, p. 163-174, 2008.

GUTIÉRREZ, M.; MIRANDA, D.; CÁRDENAS, J. Efecto de tratamientos pregerminativos sobre la germinación de semillas de gulupa (Passiflora edulis Sims.), granadilla (Passiflora ligularis Juss.) y cholupa (Passiflora maliformis L.). Revista Colombiana de Ciencias Horticolas, Bogotá, v. 5, n. 2, p. 209-219, 2011.

HABTE, M.; MANJUNATH, A. Categories of vesiculararbuscular mycorrhizal dependency of host species. Mycorrhiza, Berlin, v. 1, n. 1, p. 3-12, 1991.

HERRERA-PERAZA, R. et al. Soil-strain compatibility: the key to effective use of arbuscular mycorrhizal inoculants? Mycorrhiza, Berlin, v. 21, n. 1, p. 183-193, 2011.

KORMANIK, P. P.; MCGRAW, A. C.; SHULTZ, R. C. Procedures and equipment for staining large number of plant roots for endomycorrhizal assay. Canadian Journal of Microbiology, Ottawa, v. 26, n. 1, p. 536-538, 1980.

MABUNDZA, R.; WAHOME, P.; MASARIRAMBI, M. Effects of different pregermination treatment methods on the germination of passion (Passiflora edulis) seeds. Journal of Agriculture \& Social Sciences, Faisalabad, v. 6, n. 1, p. 57-60, 2010.

MIRANDA, D.; PÉREZ, M.; MAGNITSKIY, S. Propagación de especies pasifloráceas. In: SOCIEDAD COLOMBIANA DE CIENCIAS HORTÍCOLAS. Cultivo, poscosecha y comercialización de las pasifloráceas en Colombia: maracuyá, granadilla, gulupa y curuba. Bogotá: SCCH, 2009. p. 69-95.

MURPHY, J.; RILEY, J. P. A modified single solution method for the determination of phosphate in natural waters. Analytica Chemica Acta, Amsterdam, v. 27, n. 1, p. 31-36, 1962.

MUTHUKUMAR, T. et al. Distribution of roots and arbuscular mycorrhizal associations in tropical forest types of Xishuangbanna, southwest China. Applied Soil Ecology, Amsterdam, v. 22, n. 1, p. 24-53, 2003.

NAKASONE, H.; PAULL, R. Tropical fruits. Washington, DC: CAB Internacional, 1998.

OLIVEIRA, M. de S. et al. Arbuscular mycorrhizal fungi (AMF) affects biomolecules content in Myracrodruon urundeuva seedlings. Industrial Crops and Products, Amsterdam, v. 50, n. 1, p. 244-247, 2013.

OSORIO, N. Microorganismos del suelo y su efecto sobre la disponibilidad de nutrientes en suelos ácidos del trópico. Suelos Ecuatoriales, Bogotá, v. 41, n. 1, p. 74-91, 2011.

OZANE, P.; SHAW, T. Phosphate sorption by soils as a measure of the phosphate requirement for pasture growth. Australian Journal of Agricultural Research, Melbourne, v. 18, n. 1, p. 601-612, 1967.

PHILLIPS, J.; HAYMAN, D. Improved procedures for clearing roots and staining parasitic and vesicular arbuscular mycorrhizal fungi for rapid assessment of infection. Transactions of the British Mycological Society, London, v. 55, n. 1, p. 158-161, 1970.

PIERART, A. et al. Antimony bioavailability: knowledge and research perspectives for sustainable agricultures. Journal of Hazardous Materials, Amsterdam, v. 289, n. 1, p. 219-234, 2015.

PINZÓN, I.; FISCHER, G.; CORREDOR, G. Determinación de los estados de madurez del fruto de la gulupa (Passiflora edulis Sims.). Agronomia Colombiana, Bogotá, v. 25, n. 1, p. 83-95, 2007.

PLENCHETTE, C.; FORTÍN, J.; FURLAN, V. Growth responses of several plant species to mycorrhizae in a soil of moderate P-fertility. Plant and Soil, Amsterdam, v. 70, n. 1, p. 211-217, 1983 . 
PORTER, W. The "most probable number" method for enumerating infective propagules of vesicular arbuscular mycorrhizal fungi in soil. Australian Journal of Soil Research, Clayton, v. 17, n. 1, p. 515-519, 1979.

PRUTHI, J. Physiology, chemistry and technology of passion fruit. Advances in Food Research, San Diego, v. 12, n. 1, p. 203-282, 1963.

RAMIREZ, J. G. et al. Alternativas microbiológicas para mejorar el crecimiento del caupí. Revista de la Facultad Nacional de Agronomía de Medellín, Medellín, v. 66, n. 2, p. 7035-7044, 2013.

RIASCOS, D.; QUIROGA, I.; HOYOS, L. Análisis de la sintomatología de la roña en gulupa (Passiflora edulis f. edulis Sims.). Agronomia, Caldas, v. 19, n. 1, p. 20-30, 2011.

RIVERA, B. et al. Manejo integral del cultivo de la granadilla (Passiflora ligularis Juss.). Manizales: Litoas, 2002.

RODRÍGUEZ, H. et al. Genetics of phosphate solubilization and its potential applications for improving plant growthpromoting bacteria. Applied Soil Ecology, Amsterdam, v. 26, n. 1, p. 249-255, 2003.

ROVEDA, G. et al. Efecto de las micorrizas arbusculares sobre la aclimatación y endurecimiento de microplántulas de mora (Rubus glaucus). Revista Corpoica, Bogotá, v. 8, n. 1, p. 28-36, 2007.

RUGGIERO, C. et al. Maracujá para exportação: aspectos técnicos da produção. Brasília, DF: Frupex-Embrapa, 1996.

SIERRA, J.; CASTRO, D.; OSORIO, N. Dependencia micorrizal de laurel. Colombia Forestal, Bogotá, v. 12, n. 1, p. 17-24, 2009.

YANO, K.; TAKAKI, M. Mycorrhizal alleviation of acid soil stress in the sweet potato (Ipomoea batatas). Soil Biology \& Biochemistry, London, v. 37, n. 1, p. 15691572, 2005.

ZANDAVALLI, R.; DILLENBURG, L.; SOUZA, P. de. Growth responses of Araucaria angustifolia (Araucariaceae) to inoculation with the mycorrhizal fungus Glomus clarum. Applied Soil Ecology, Amsterdam, v. 25, n. 1, p. 245-255, 2004.

ZOU, Y. et al. Mycorrhizal-mediated lower proline accumulation in Poncirus trifoliata under water deficit derives from the integration of inhibition of proline synthesis with increase of proline degradation. PLoS ONE, San Francisco, v. 8, n. 11, 2013. Available at: http:// journals.plos.org/plosone/article?id=10.1371/journal. pone.0080568. Acess in: 2014. 